\title{
The capsule polysaccharide structure and biogenesis for non-O I Vibrio cholerae NRT36S: genes are embedded in the LPS region Yuansha Chen ${ }^{1}$, Peter Bystricky ${ }^{2,6}$, Jacob Adeyeye ${ }^{2,7}$, Pinaki Panigrahi' ${ }^{3}$, Afsar Ali ${ }^{1}$, Judith A Johnson ${ }^{4}, 5$, CA Bush ${ }^{2}$, JG Morris $\mathrm{Jr}^{1}$ and OC Stine*1
}

\begin{abstract}
Address: ${ }^{1}$ Department of Epidemiology and Preventive Medicine, University of Maryland, Baltimore, Baltimore, MD 21201, USA, ${ }^{2}$ Department of Chemistry and Biochemistry, University of Maryland, Baltimore County Baltimore, MD 21250, USA, ${ }^{3}$ Department of Pediatrics, University of Maryland, Baltimore, Baltimore, MD 21201, USA, ${ }^{2}$ Department of Pathology, University of Maryland, Baltimore, Baltimore, MD 21201, USA, ${ }^{5}$ Clinical Microbiology, Veterans Affairs Maryland Health Care System, Baltimore, MD 21201, USA, ${ }^{6}$ Slovak Medical University; Bratislava, SK83303, Slovakia and ${ }^{7}$ Department of Natural Sciences, Coppin State College, Baltimore, MD 21216, USA

Email: Yuansha Chen - ychen@epi.umaryland.edu; Peter Bystricky - peter.bystricky@szu.sk; Jacob Adeyeye - jadeyeye@coppin.edu; Pinaki Panigrahi - ppanigrahi@peds.umaryland.edu; Afsar Ali - aali@epi.umaryland.edu; Judith A Johnson - Judy.Johnson2@va.gov; CA Bush - bush@chem.umbc.edu; JG Morris - Jmorris@epi.umaryland.edu; OC Stine* - ostin001@umaryland.edu

* Corresponding author
\end{abstract}

Published: 15 March 2007

BMC Microbiology 2007, 7:20 doi:10.1 186/147/-2180-7-20
Received: 30 August 2006

Accepted: 15 March 2007

This article is available from: http://www.biomedcentral.com/I47/-2/80/7/20

(C) 2007 Chen et al; licensee BioMed Central Ltd.

This is an Open Access article distributed under the terms of the Creative Commons Attribution License (http://creativecommons.org/licenses/by/2.0), which permits unrestricted use, distribution, and reproduction in any medium, provided the original work is properly cited.

\begin{abstract}
Background: In V. cholerae, the biogenesis of capsule polysaccharide is poorly understood. The elucidation of capsule structure and biogenesis is critical to understanding the evolution of surface polysaccharide and the internal relationship between the capsule and LPS in this species. V. cholerae serogroup O3I NRT36S, a human pathogen that produces a heat-stable enterotoxin (NAG-ST), is encapsulated. Here, we report the covalent structure and studies of the biogenesis of the capsule in V. cholerae NRT36S.
\end{abstract}

Results: The structure of the capsular (CPS) polysaccharide was determined by high resolution NMR spectroscopy and shown to be a complex structure with four residues in the repeating subunit. The gene cluster of capsule biogenesis was identified by transposon mutagenesis combined with whole genome sequencing data (GenBank accession DQ915177). The capsule gene cluster shared the same genetic locus as that of the O-antigen of lipopolysaccharide (LPS) biogenesis gene cluster. Other than V. cholerae OI39, this is the first V. cholerae CPS for which a structure has been fully elucidated and the genetic locus responsible for biosynthesis identified.

Conclusion: The co-location of CPS and LPS biosynthesis genes was unexpected, and would provide a mechanism for simultaneous emergence of new $\mathrm{O}$ and $\mathrm{K}$ antigens in a single strain. This, in turn, may be a key element for $V$. cholerae to evolve new strains that can escape immunologic detection by host populations.

\section{Background}

Vibrio cholerae has three forms of surface polysaccharide, although some strains do not express all three forms: a lipopolysaccharide (LPS) inserted in the outer membrane, a capsule composed of high molecular weight polysaccharide that forms a dense thick coat outside of the bacterial cells, and a loose slime-like exopolysaccharide. Unlike $V$. cholerae of serogroup O1, which causes cholera, most non- 
O1 isolates have capsular polysaccharide (CPS) in addition to LPS. The LPS of $V$. cholerae is a protective antigen for cholera $[1,2]$, with over 200 serogroups identified based on the $\mathrm{O}$-antigen of the LPS. The O-antigen biogenesis loci of 4 serogroups (O1, O139. O22, O37) have been sequenced and characterized, and have been found to reside between two genes, gmhD and rjg, in the genome [3-7]. More than $85 \%$ of non-O1 V. cholerae isolates have a capsule that is critical for virulence in extraintestinal infections [8]. However, in contrast to E. coli, in which extensive work has been done on capsule structure and genetics (with associated classification into groups by Whitfield and Roberts [9]), structures and the genetics of CPS in V. cholerae are poorly understood.

The one strain for which data on capsule structure and genetics are available is the newly emerged epidemic strain $V$. cholerae O139. This strain has a capsule that appears to have arisen from the replacement of the $\mathrm{O} 1$ antigen biosynthetic region with a new gene cluster in the genetic background of an $\mathrm{O} 1$ strain $[5,6]$, resulting in emergence of a strain to which the human population did not yet have immunity. The capsule in $\mathrm{O} 139$ is unusual in that it shares the same repeating subunit as the $\mathrm{O}$-antigen [10-12]. Therefore, the polysaccharide in O139 appears as both capsule and LPS and resembles the $\mathrm{K}_{\mathrm{LPS}}$ in the group 4 E. coli capsule [9].

There are limited studies on the genetics of polysaccharide biogenesis for the genus Vibrio. In V. vulnificus the CPS is a primary virulence factor and hence has been the target of more intensive study [13]. An operon including genes $w z a, w z b$ and $w z c$ was identified as part of the CPS genes for V. vulnificus strain M06-24 [14,15], consistent with the presence of a group 1 capsule. The genetic loci for CPS were also identified in another strain of $V$. vulnificus 1003 [16]. A wzx/wzy system was present for polymerization and exporting the CPS. However, the genetic region responsible for LPS biosynthesis has not been identified in V. vulnificus.

The elucidation of capsule structure and biogenesis is critical to understanding the evolution of surface polysaccharide and the internal relationship between the capsule and LPS in this species. It also has clear implications for understanding the behavior of this species within human populations, as the ability to change these surface antigens to avoid host immunologic detection is a key feature underlying the ability of $V$. cholerare to survive. Here, we report the covalent structure and studies of the biogenesis of the capsule in $V$. cholerae NRT36S.

\section{Results and discussion Structure of the CPS \\ Gas chromatography}

Carbohydrate analysis was done by gas chromatography of the trimethyl silyl methyl glycosides and the absolute configurations were determined by gas chromatography of the + and - 2-butyl glycosides as the trimethyl silyl derivatives. Both experiments were performed at the Complex Carbohydrate Research Center (CCRC) at the University of Georgia. The results indicated L-rhamnose (Rha), D-glucosamine (GlcNAc), D-glucuronic acid (GlcA) and D-galactose (Gal). The results of methylation analysis, also performed at CCRC, are given in Table 1. These results indicate that the major components of the hydrolyzed sample of methylated CPS sample represent 3linked L-rhamnose, 4-linked D-glucosamine, 4- and 6linked D-glucosamine and galactose in various linkages including 3-linked, 4-linked and 3,4 -linked. The D-glucuronic acid residue cannot be detected by this analysis because the uronic acids are converted to a sodium salt in the standard protocol [17].

Nuclear magnetic resonance (NMR) results

NMR spectra of the native polysaccharide are complex, showing a number of peaks in the anomeric region that are not in simple stoichiometric ratios. Likewise, the acetyl methyl region $(2.0-2.3 \mathrm{ppm})$ shows approximately 10 peaks not in simple ratios suggesting that the polysaccharide may be heterogeneously substituted with $\mathrm{O}$-acetyl functions. Therefore the sample was treated with aqueous ammonium hydroxide, which is expected to cleave $\mathrm{O}$-acetyl groups by mild base catalyzed hydrolysis. The NMR spectra of the resulting sample (de-O-acetyl polysaccharide) showed only two peaks in the acetyl methyl region (2.06 and $2.09 \mathrm{ppm}$ ) and a greatly simplified pattern in the anomeric region with four distinct signals in the C-H HSQC (heteronuclear single quantum

Table I: Results of methylation analysis.

\begin{tabular}{cc}
\hline Glycosyl residue & Percentage present \\
\hline 3-linked Rha & 25 \\
terminal Gal & 4 \\
3,4-linked Rha & 2 \\
3-linked Gal & 13 \\
4-linked Gal & 8 \\
4-linked Glc & 3 \\
2- and 4-linked Gal & 3 \\
3- and 4-linked Gal & 4 \\
3- and 6-linked Gal & 4 \\
4- and 6-linked Gal & 1 \\
Terminal GlcNAc & 2 \\
4-linked GlcNAc & 17 \\
4- and 6-linked GlcNAc & 14 \\
\end{tabular}


correlation) spectrum. We show below that the peaks at 2.06 and 2.09 arise from $\mathrm{N}$-acetyl groups.

The HSQC spectrum (Figure 1A\&1B) indicates four sugar residues in the repeating subunit of the polysaccharide and the four signals were arbitrarily assigned identifying letters, A, B, C and D for the purpose of individual sugar identification using homonuclear ${ }^{1} \mathrm{H}$ spin correlation. Experiments used to identify the sugar ring spin systems included COSY (correlation spectroscopy), TOCSY (total correlation spectroscopy), HMBC (heteronuclear multiple bond coherence) and NOESY (nuclear Overhauser spectroscopy). Residue $\mathrm{C}$ is identified as rhamnose by the characteristic methyl resonance of the 6-deoxy sugar at $1.33 \mathrm{ppm}$ in combination with the equatorial configuration of $\mathrm{H} 2$ indicated by its small homonuclear coupling constants. The anomeric configuration is identified as $\beta$ by large NOESY peaks between $\mathrm{H} 1, \mathrm{H} 3$ and $\mathrm{H} 5$ as well as by ${ }^{1} \mathrm{~J}_{\mathrm{CH}}=162 \mathrm{~Hz}$. Residues $\mathrm{B}$ and $\mathrm{D}$ are identified as amino sugars by the characteristic chemical shift of $\mathrm{C} 2$ and as glucosamine by homonuclear coupling values. Residue $\mathrm{B}$ has the $\alpha$-anomeric configuration as indicated by small $\mathrm{J}_{\mathrm{H} 1-\mathrm{H} 2}$ and by ${ }^{1} \mathrm{~J}_{\mathrm{CH}}=172 \mathrm{~Hz}$ while residue $\mathrm{D}$ has the $\beta$ - configuration as indicated by large $\mathrm{J}_{\mathrm{H} 1-\mathrm{H} 2}$ and by ${ }^{1} \mathrm{~J}_{\mathrm{CH}}=$ $158 \mathrm{~Hz}$. The fourth residue, A, is identified as $\alpha$-glucuronic acid. ${ }^{1} \mathrm{~J}_{\mathrm{CH}}$ for the anomeric signal is $168 \mathrm{~Hz}$. and $\mathrm{J}_{\mathrm{H} 1-\mathrm{H} 2}$ is small, but the coupling constants of $\mathrm{H} 3, \mathrm{H} 4$ and $\mathrm{H} 5$ are all large as expected for the gluco configuration. No crosspeaks can be detected for H6 but an HMBC spectrum selective for the carbonyl region shows crosspeaks between both $\mathrm{H} 4$ and $\mathrm{H} 5$ and a carbonyl resonance at $176.7 \mathrm{ppm}$ consistent with $\alpha$-glucuronic acid. The central part and the anomeric region of the HSQC spectrum of the de-O-acetyl polysaccharide are shown in Figure $1 \mathrm{~A} \& 1 \mathrm{~B}$ and the complete ${ }^{1} \mathrm{H}$ and ${ }^{13} \mathrm{C}$ resonance assignments are given in Table 2. The glycosidic linkages between the four residues were determined from HMBC and NOESY data as indicated in Table 3. While no HMBC peaks could be observed for the D-B linkage, the nuclear Overhauser data clearly indicate a $\beta-1-6$ linkage and the downfield chemical shift of B-C6 at 68.9 ppm confirms this linkage assignment. The proposed structure of the tetrasaccharide repeating unit is given in Figure 2.

Having determined the structure of the sugar backbone, we turned to the acetylated forms of the polysaccharide. While interpretation of their complex spectra was made difficult by heterogeneity, it was possible given the basic sugar structure. Base hydrolysis milder than that required to produce the de-O-acetyl polysaccharide yielded a sample with NMR spectra having peaks in stoichiometric ratios (mono-O-acetyl polysaccharide). The single $\mathrm{O}$ acetyl group is assigned by carbonyl-selective HMBC to the 2-position of rhamnose (C), a position resistant to base hydrolysis due to the absence of a neighboring hydroxyl function. A complete set of homonuclear and heteronuclear NMR spectra of a sample of this form of the polysaccharide in $\mathrm{H} 2 \mathrm{O}$ solution allowed assignment of signals of the amide protons of residues $\mathrm{B}$ and $\mathrm{D}$ confirming that they are $\mathrm{N}$-acetyl amino sugars. The complete assignment of the NMR spectrum of the mono-O-acetyl polysaccharide is given in Table 4 .

The acetate methyl region of the NMR spectrum of the native, untreated, polysaccharide shows a number of peaks including those assignable to the amides of residue $\mathrm{B}$ and $\mathrm{D}$ and of the 2-O-acetyl group of residue $\mathrm{C}$ along with smaller peaks indicating partial $\mathrm{O}$-acetylation at other positions. Using HMBC spectra, it was possible to correlate methyl proton signals, through carbonyl carbon resonances, to sugar ring protons indicating positions of acetyl substitution. In addition to the 2-O-acetyl of residue $\mathrm{C}$, it was possible to identify an $\mathrm{O}$-acetyl group on the 3-position of residue $\mathrm{B}$ to the extent of about $50 \%$ as indicated in Table 4. Anomeric resonances of residue A were split into three peaks in the native polysaccharide suggesting partial O-acetylation of that residue but the exact positions could not be definitively assigned.

Although the chromatographic data indicate that the sample contains galactose, it is not part of the capsular polysaccharide. The NMR data of Figure 1 are consistent with four residues per repeating subunit and no sign of any galactose. Although the NMR spectra show minor peaks at approximately $10 \%$ level, none are characteristic of carbohydrates and they show no connection to the peaks assigned for the polysaccharide structure by NOESY or HMBC spectra.

The structure proposed here for the NRT36S capsule repeating subunit is very similar to that reported for the $V$. cholerae O6 lipopolysaccharide [18]. The polysaccharide backbones are identical differing only in the degrees of $\mathrm{O}$ acetylation. Bergstrom et al reported stoichiometric Oacetylation at both $\mathrm{C} 2$ of rhamnose and at C3 of $\alpha$-GlcNAc while our structure for native capsular polysaccharide of $V$. cholerae NRT36S is only partially substituted at C3 of $\alpha$-GlcNAc along with lower degrees of acetylation at other positions. In spite of these differences, the NMR data reported by Bergstrom et al [18] are quite close to those reported for our native structure in Table 4 .

\section{Transposon mutagenesis and mutant selection}

The conjugations between wild type Vibrio cholerae NRT36S and donor strain E. coli S17 $\lambda$ pir/putKm-2 generated 20,615 mutants of NRT36S, each carrying a single copy of the transposon $\mathrm{Km}-2$ in its genome. Among these mutants, 411 colonies displayed a translucent phenotype on LB agar. This phenotype suggests that genes involved in 
A.

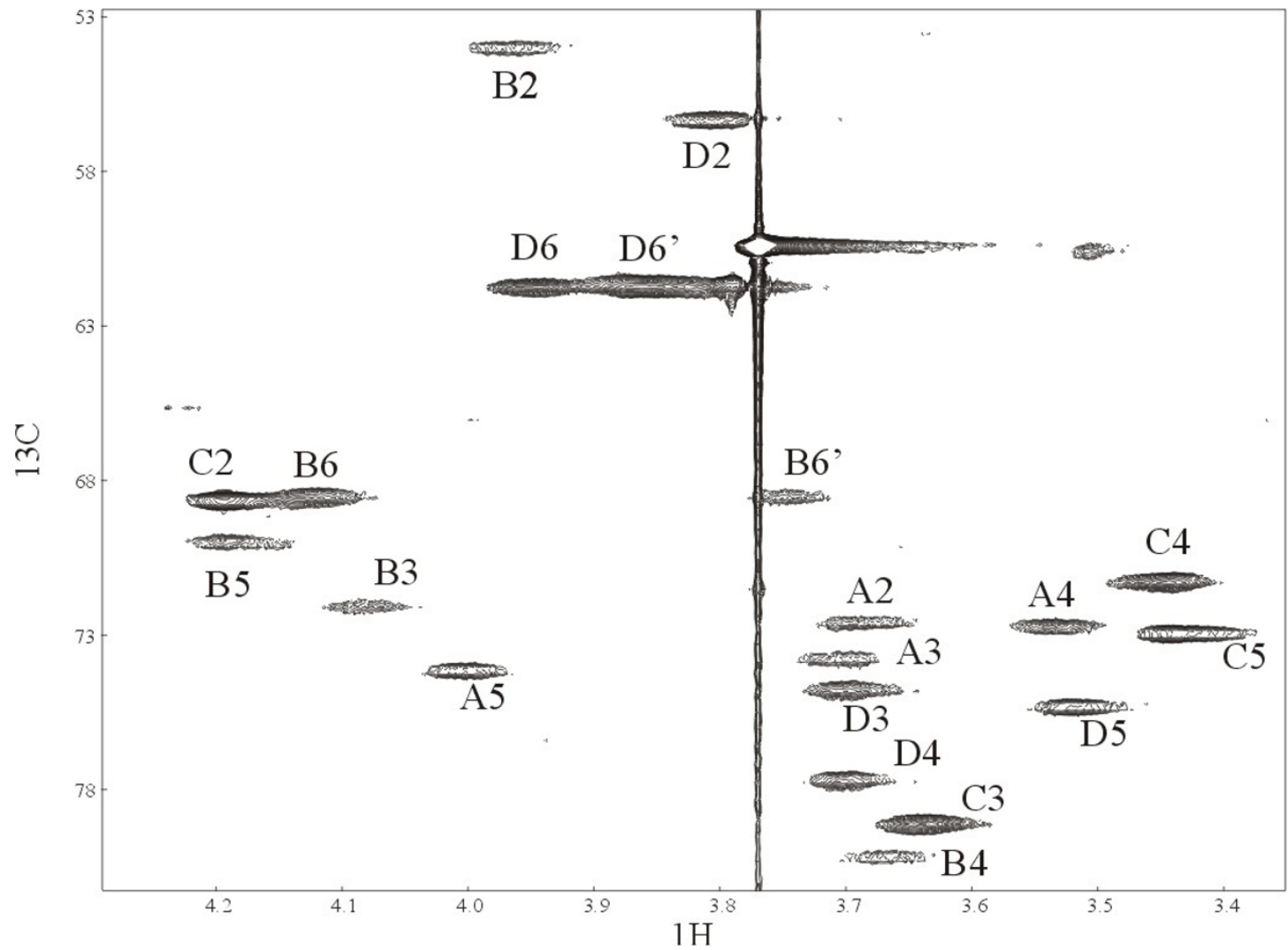

B.

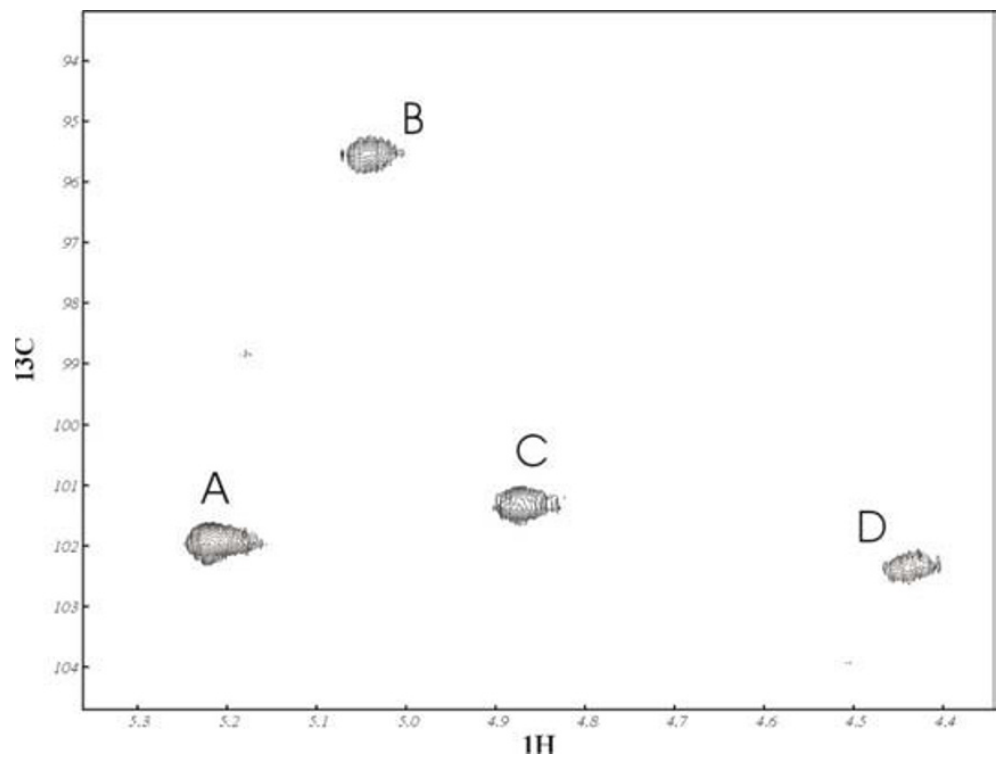

Figure I

Panel A shows the HSQC spectrum of the de-O-acetylated capsular polysaccharide from NRT36S. The strong signal at 3.78, 60 $\mathrm{Ppm}$ is a low molecular weight impurity. Panel B shows the signal from the anomeric region. The methyl group region is not shown. 
Table 2: Complete assignment of the NMR spectra of the de-O-acetylated polysaccharide

\begin{tabular}{|c|c|c|c|c|c|c|}
\hline \multirow[t]{2}{*}{ NRT36 (deOAc) $\sim 50^{\circ} \mathrm{C}(32 \mathrm{I} \mathrm{K})$} & $\mathrm{H}-\mathrm{I}$ & $\mathrm{H}-2$ & $\mathrm{H}-3$ & $\mathrm{H}-4$ & $\mathrm{H}-5$ & $\mathrm{H}-6, \mathrm{H}-6$ \\
\hline & C-I & $\mathrm{C}-2$ & $\mathrm{C}-3$ & $\mathrm{C}-4$ & C-5 & C-6 \\
\hline \multirow[t]{2}{*}{ A: $\alpha-D-G \mid c A$} & 5.19 & 3.66 & 3.67 & 3.50 & 3.97 & - \\
\hline & 101.9 & 72.7 & 73.8 & 72.7 & 74.1 & 176.7 \\
\hline \multirow[t]{2}{*}{ B: $\alpha$-D-GlcNAc } & 5.01 & 3.93 & 4.05 & 3.64 & 4.16 & $4.09,3.71$ \\
\hline & 95.5 & 53.9 & 72.0 & 80.2 & 69.9 & 68.6 \\
\hline \multirow[t]{2}{*}{ C: $\beta$-L-Rha } & 4.85 & 4.16 & 3.61 & 3.42 & 3.40 & 1.33 \\
\hline & 101.3 & 68.6 & 79.1 & 71.2 & 72.9 & 17.6 \\
\hline \multirow[t]{2}{*}{ D: $\beta$-D-GlcNAc } & 4.42 & 3.78 & 3.67 & 3.67 & 3.49 & $3.83,3.92$ \\
\hline & 102.3 & 56.3 & 74.7 & 77.6 & 75.3 & 61.7 \\
\hline
\end{tabular}

capsule biogenesis have been disrupted by the transposon [19].

\section{DNA analysis of mutants}

Genomic DNA was isolated from the translucent mutants and analyzed by inverted polymerase chain reaction (PCR) and sequencing, identifying 13 unique insertion sites in 11 genes. Since NRT36S can also undergo spontaneous phase variation between transluscent and opaque colony morphologies, isolates with the 13 insertions were tested for complement resistance [19]. Nine insertions in eight genes were sensitive to serum killing and showed no reversion to the opaque morphology (Table 5). Isolates with insertions in the other 3 genes reverted to opaque colonies and were resistant to serum killing and therefore were excluded from further analysis. Only four of the stable mutant genes related to sugar modification and processing and were considered as putative structural genes for the biogenesis of the NRT36S capsule. The function of the other genes was unclear. One of the putative structural genes had a homolog in the fully sequenced genome of $V$. cholerae N16961, a serogroup O1 pandemic strain. Orf23, a homolog of VC0262, an UDP-glucose 4epimerase (galE) was disrupted in translucent colony TR3. TR3 was restored to opaque phenotype and resistant to serum killing when complemented with gal $E$ gene. The

Table 3: Residue linkages for the capsular polysaccharide of $V$. cholerae NRT36S

\begin{tabular}{lll}
\hline Linkage & HMBC & NOESY \\
\hline A-B & ACI-BH4 & \\
& AHI-BC4 & \\
B-C & BHI-CC3 & BHI-CH2 \\
& & BHI-CH3 \\
C-D & CHI-DC4 & CHI-DH4 \\
D-B & & DHI-BH6 \\
& & DHI-BH6 \\
\hline
\end{tabular}

other three structural genes identified by transposon mutagenesis did not have homologs in the genome of $V$. cholerae N16961. In translucent colony TR17, a glycosyltransferase gene was disrupted and a rhamnosyltransferase gene was disrupted in both TR43 and TR287. An $\mathrm{ABC}$ transporter system integral membrane protein gene $w z m$ was disrupted in TR296. The VC0262 homolog and the 3 other genes are typical of genes commonly found in polysaccharide biogenesis.

\section{Immuno blotting and size exclusion chromatography (SEC)} SEC data indicated that the molecular weight of the NRT36S capsule is greater than 670k Dalton (Figure $3 \mathrm{~A} \& 3 \mathrm{~B})$. The antiserum raised against the whole cell of $V$. cholerae NRT36S did not detect anything close to that molecular weight of CPS in the immuno blot (Figure 4), indicating that the antibodies did not react with the capsule. This result was consistent with the previous finding [20]. Nevertheless, the antibodies detected some polysaccharides that formed a ladder pattern in the molecular weight range of $20 \mathrm{k}$ to $40 \mathrm{k}$ Dalton (Figure 4). We believed these were the LPS. Interestingly, the amount of reactive LPS to the antibody was reduced in mutants TR3, TR17, and TR296. Analysis of the capsule preps by SEC from the mutants showed that three of the mutants, TR3, Tr287 and TR43 had completely lost the high molecular weight peaks corresponding to the capsule while in TR17 and TR296, the amount of capsule was significantly reduced (Figure 3B).

\section{Electron microscopy (EM)}

We evaluated thin sections of wild type $V$. cholerae NRT36S and several translucent mutants stained with polycationic ferritin by EM. Representative profiles are shown in Figure 5. As seen before ([19], NRT36S displayed a heavy, complete capsule surrounding the cell (Figure 5A). TR3 did not have a complete capsule, but had some patches of capsule materials (Figure 5B). Both of TR17 and TR296 had a much thinner capsule compared to 


\title{
(Ac-O)
}

\author{
$\uparrow$ \\ $\begin{array}{llll}\text { D } & 3 & \text { B } & \text { C }\end{array}$ \\ $\rightarrow 4)-\beta$-D-Glc $p$ NAc-( $1 \rightarrow 6)-\alpha-D-G l c p N A c-(1 \rightarrow 3)-\beta$-L-Rhap $(1 \rightarrow$ \\ 4 \\ 1 \\ 2 \\ $\uparrow$ \\ Ac-O

\section{$\alpha-\mathrm{D}-\mathrm{Glc} p \mathrm{~A}$}

Figure 2

Proposed structure of NRT36S CPS repeating unit. Parentheses indicate partial O-acetylation of residue B at the 3-position.

opaque NRT36S (Figure 5C\&5D). EM pictures for all three mutants were consistent with the amounts of capsule observed by SEC (Figure 3B).

\section{Sequencing of the V. cholerae NRT36S genome}

$V$. cholerae NRT36S genome was sequenced by the company 454 Life Sciences. The sequencing runs have generated 1,082,967 reads and output 104,531,256 bases of sequence. The estimated coverage depth was $26 \mathrm{X}$. The draft genome consisted of 184 contigs with total length of 3.9 million bases. The average GC (guanine-cytosine) content for the draft genome was $47.5 \%$. The draft genome was annotated [21,22]. For the purpose of the discussion in this paper, only those features related to the polysaccharide biogenesis will be discussed.

\section{Genetics of the polysaccharide biogenesis $O$-antigen region}

In previous studies, the O-antigen biogenesis genes for $V$. cholerae had been identified to cluster at one locus in the genome, between genes $g m h D$ and rjg [3,4,6,23]. After aligning the contigs of the draft genome of $V$. cholerae NRT36S to the fully sequenced genome of $V$. cholerae N16961 [24], we found that 3 contigs (contigs 34, 19, 78) of NRT 36S can partially align to the O-antigen region of N16961. Contig 34 contains $g m h D$ gene and contig 78 contains rjg gene. Contig 19 falls into the middle of contig 34 and 78. The sequence information from analyzing the transposon mutagenesis mutants was able to pick up two more contigs (contig 98 and 43) and connect them to contig 19. Therefore $g m h D$ and rjg were separated by 5 contigs in the NRT36S genome. The gaps between these contigs were filled and we ratified this region, between $g m h D$ and $r j g$, as the putative $\mathrm{O}$-antigen biogenesis region (Figure 6) for $V$. cholerae NRT36S. The sequence between $g m h D$ and rig was deposited into GenBank (accession DQ915177).

\section{CPS region}

We located the capsule biogenesis genes identified by transposon mutagenesis in the NRT36S genome (Table $5)$. To our surprise, the 4 putative capsule structural genes identified by transposon mutagenesis were all located between the genes $g m h D$ and $r j g$, the region considered to encode $\mathrm{O}$-antigen biogenesis (Figure 6). Theses four genes were knocked out by at least one of 5 independent transposition events and caused the translucent phenotype associated with the loss of the capsule in each case. There- 
Table 4: Complete assignment of the NMR spectra of the mono-O-acetylated polysaccharide

\begin{tabular}{|c|c|c|c|c|c|c|}
\hline \multirow[t]{2}{*}{ NRT36 Mono-O-Acetyl $\sim 50^{\circ} \mathrm{C}$} & $\mathrm{H}-\mathrm{I}$ & $\mathrm{H}-2$ & $\mathrm{H}-3$ & $\mathrm{H}-4$ & $\mathrm{H}-5$ & $\mathrm{H}-6, \mathrm{H}-6^{\prime}$ \\
\hline & C-I & $C-2$ & $C-3$ & C-4 & C-5 & C-6 \\
\hline \multirow[t]{2}{*}{ A: $\alpha$-D-GlcA } & 5.15 & 3.63 & 3.67 & 3.51 & 3.95 & - \\
\hline & 101.9 & 72.7 & 73.8 & 72.7 & 74.1 & 176.7 \\
\hline \multirow[t]{2}{*}{ B: $\alpha$-D-GlcNAc } & $4.99(5.01)$ & $3.91(4.05)$ & $3.99(5.27)$ & $3.63(3.87)$ & 4.14 & $4.09,3.71$ \\
\hline & $94.9(94.1)$ & $53.9(52.6)$ & $71.6(74.3)$ & 80.3 & 68.6 & 68.4 \\
\hline \multirow[t]{2}{*}{ C: $\beta$-L-Rha } & 5.04 & 5.53 & 3.80 & 3.48 & 3.49 & 1.36 \\
\hline & 99.9 & 69.9 & 76.3 & 71.6 & 73.2 & 17.6 \\
\hline \multirow[t]{2}{*}{ D: $\beta$-D-GlcNAc } & 4.39 & 3.77 & 3.66 & 3.69 & 3.43 & $3.90,3.88$ \\
\hline & 102.1 & 56.3 & 74.7 & 77.8 & 75.1 & 61.7 \\
\hline
\end{tabular}

a.) Shifts enclosed in parentheses are those of the 3-O-acetylated $B$ residue in the native polysaccharide.

\begin{tabular}{cccc}
\hline assignment of NAc's, OAc's & $\mathrm{N} \underline{\mathrm{H}}$ & $\mathrm{C}=\mathrm{O}$ & $\mathrm{CH}_{3}$ \\
\hline B: $\alpha$-D-GlcNAc & 7.79 & 174.9 & $22.93 ; 2.03$ \\
D: $\beta$-D-GlcNAc & 8.09 & 175.2 & $23.19 ; 2.08$ \\
C: $\beta$-L-Rha OAc & & 173.9 & $21.26 ; 2.21$ \\
\hline
\end{tabular}

fore, we believe that the $\mathrm{O}$-antigen biogenesis region in $V$. cholerae NRT36S is also the capsule biogenesis region.

\section{Global features}

The locus of CPS/O-antigen was 49,916 base pairs in length between genes $g m h D$ and rjg. There were 46 open reading frames (orf) (Figure 6). The annotation for each orf is listed along with a match from Genbank and its percent amino acid identity/positive, the species and the Evalue (Table 6). Twelve genes were glycosyltransferases, 16 genes were recognized as pathway genes for synthesis of the nucleotide sugar precursor for external polysaccharide, and 6 other genes were recognized as polysaccharide processing and translocation genes. The function of the other 12 genes was unknown. A JUMPstart site [25] was located just downstream from the gmhD gene. The GC content of this region was $41.2 \%$, lower than the $47.5 \%$ GC content of the genome. The disruption by transposon in orf5 $(w z m)$, an ABC transporter gene, orf8, a glycosyltransferase gene, orf23, an UDP-glucose-epimerase, (galE) and orf43, a rhamnosyltransferase gene had caused the non-encapsulation of NRT36S (Figure 3). The complementation by galE gene reverted the translucent mutant TR3 to opaque phenotype and the complemented colonies were resistant to serum killing.

\section{Glycosyltransferases}

There were 12 glycosyltransferase genes identified. The precise function of most of them remained to be elucidated. Orf45 (wecA) was an undecaprenylphosphate Nacetylglucosamine 1-phosphate transferase gene. WecA was putatively the initial transferase to catalyze the transfer of N-acetylglucosamine 1-phosphate to undecaprenylphosphate in the capsule polysaccharide synthesis.

\section{Synthesis genes}

The structural data for $V$. cholerae NRT36S indicate that the capsule contains, one residue each of rhamnose and glucuronic acid and two $\mathrm{N}$-acetyl-glucosamine residues, genes for whose synthesis are present in the CPS region. There are two sets of genes that are almost identical (orf14, and orf33-36) for L-rhamnose synthesis; they were

Table 5: CPS genes (bold print) identified by transposon mutagenesis

\begin{tabular}{lccc}
\hline Clone \# & Gene in CPS region & Putative gene functions & Best hit (AAI) \\
\hline TR2 & not & CYS regulon transcriptional activator & V. cholerae (I00\%) \\
TR23 & not & FadR fatty acid metabolism regulator protein & V. cholerae (I00\%) \\
TR286 & not & Adenylate cyclase & V.cholerae (I00\%) \\
TR301 & not & Ubiquinol cytochrome C reductase & V. cholerae (I00\%) \\
TR3 & Orf23 (galE) & Nucleoside-diphosphate sugar epimerase & V. cholerae(98\%) \\
TR17 & Orf8 & Glycosyltransferase & Nitrosospira multiformis(40\%) \\
TR43, TR287 & Orf3 & Rhamnosyltransferase & Shewanella sp. (66\%) \\
TR296 & Orf5 $(\mathbf{w z m})$ & ABC transporter system integral membrane protein & Raoultella terrigena(55\%) \\
\hline
\end{tabular}




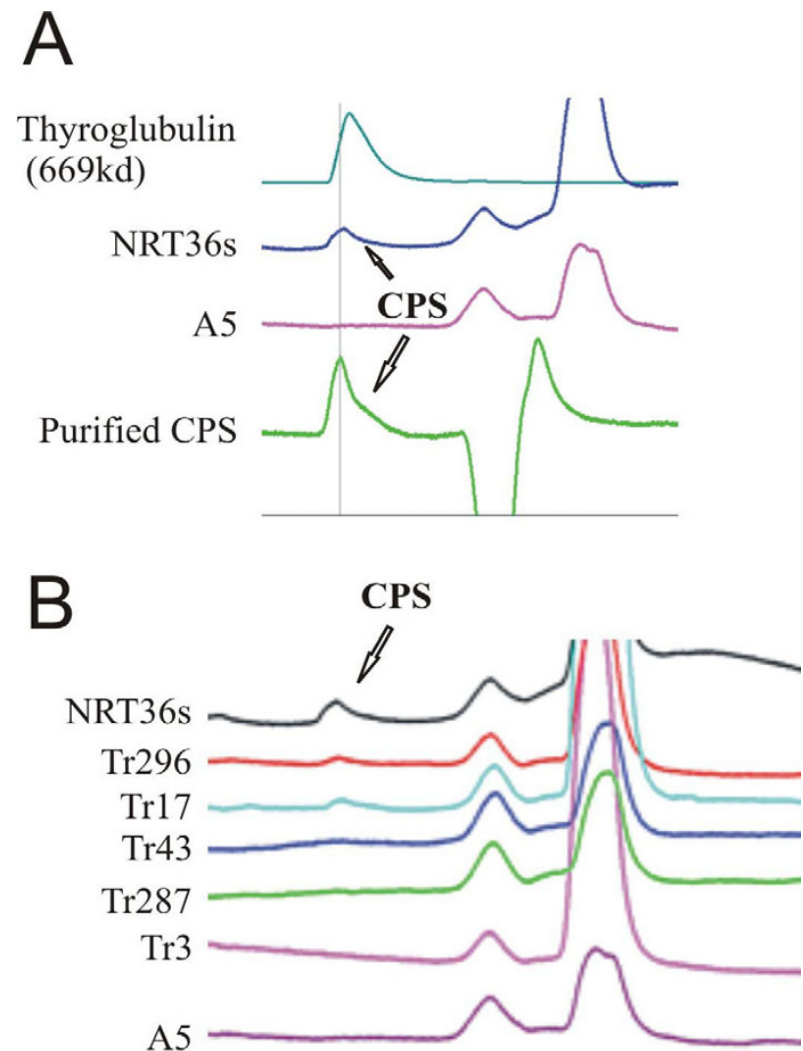

\section{Figure 3}

Size exclusion chromatography of the capsule prep. A). Capsule prep from control (NRT36S and A5) compared to purified CPS of NRT36S. The size was estimated by thyroglobulin. The arrow indicates the peak of the capsule at about 13.2 minutes retention time, which corresponds to about 670 k Dalton molecular weight. B). Capsule prep from mutants and control.

$r m l B, r m l A, r m l C$, and $r m l D$ in the order. L-rhamnose is commonly present in bacterial polysaccharides and the genes to synthesize it are normally clustered. For example in $V$. cholerae isolates with LPS serotypes O6, O12, O14, $\mathrm{O} 19$ and $\mathrm{O} 151$, the 4 orfs following $\mathrm{gmhD}$ are $\mathrm{rmlB}, \mathrm{rmlA}$, rmlC, and $r m l D$ [26]. Orf43 may be the rhamnosyltransferase to catalyze the addition of rhamnose to the CPS backbone. The disruption orf43 by the transposon both resulted in the loss of the capsule. This observation is consistent with the presence of rhamonse in the repeating polysaccharide backbone of the capsule. Orf23 was gene galE; its product UDP-glucose 4-epimerase catalyzed the conversion of UDP-glucose to UDP-galactose. Disruption of galE gene in mutant TR3 caused the loss of the capsule. Orf24 (wbeW) transfers galactose to the capsule complex. Orf 41, a sugar O-acetyltransferase homologue could be involved in the observed $\mathrm{O}$-acetylation of the capsule, but this modification of bacterial polysaccharides is not well understood and other genes may be involved as well.

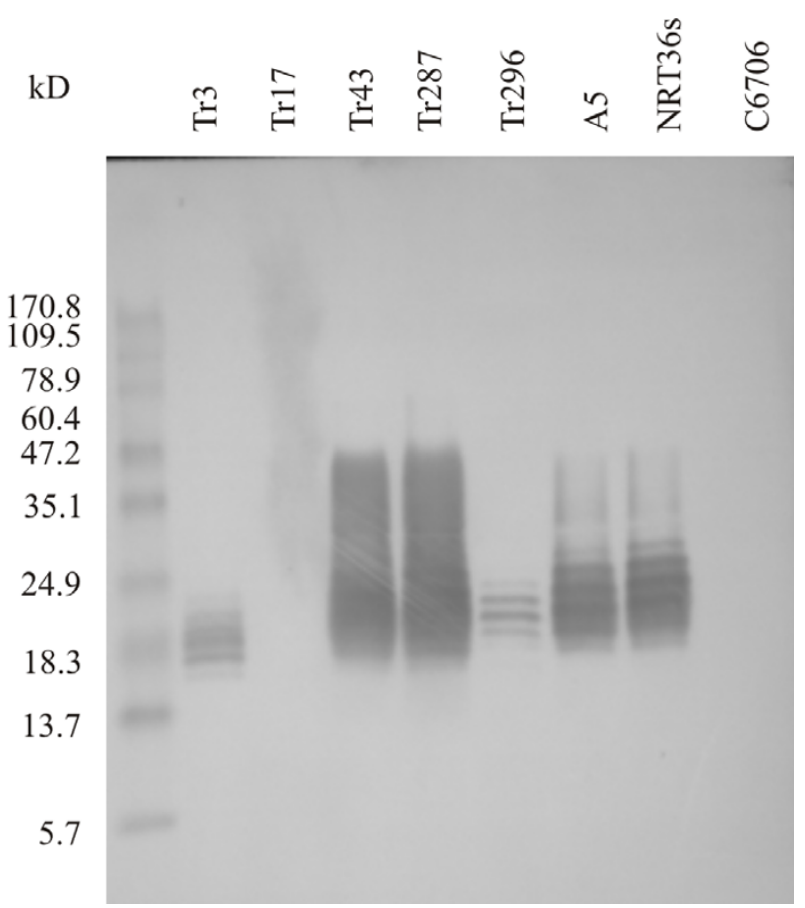

Figure 4

Immuno blot of NRT36S antiserum against external polysaccharide preparations from various strains.

Orf11, 12, 22, 37, 41 and 44 were also putative pathway genes for the synthesis of nucleotide sugar precursors, but their precise functions were not clear to us.

\section{Translocation and processing genes}

An ABC-2 type transporter system consisted of $w z m$ and $w z t$ were present in the CPS/O-antigen region. When $w z m$ was disrupted by transposon mutagenesis, the mutant was non-capsulated (Table 5). Orf38 was predicted as a polysaccharide translocase gene $w z x$. Orf40 was predicted to have several transmembrane domains by the Dense Alignment Surface (DAS) program [27] and were assigned as putative wzy. Three genes $w z a, w z b$ and $w z c$ were also present in the CPS/O-antigen region. The proteins Wza, Wzb and Wzc in E. coli formed a system that was involved in the exportation of $E$. coli group 1 capsular polysaccharides [28].

The disruption of an $\mathrm{ABC}$ transporter system integral membrane protein gene $w z m$ had significantly reduced the amount of capsule (Figure 3B) in our experiments and resulted in the translucent colonies that were susceptible to serum killing. Examination of the CPS region also revealed the existence of $w z t$, which is another component of the $\mathrm{ABC}$ transporter system. Our results suggest that the processing and translocation of the capsule in $V$. cholerae NRT36S involves the ABC transporter system. There was a 


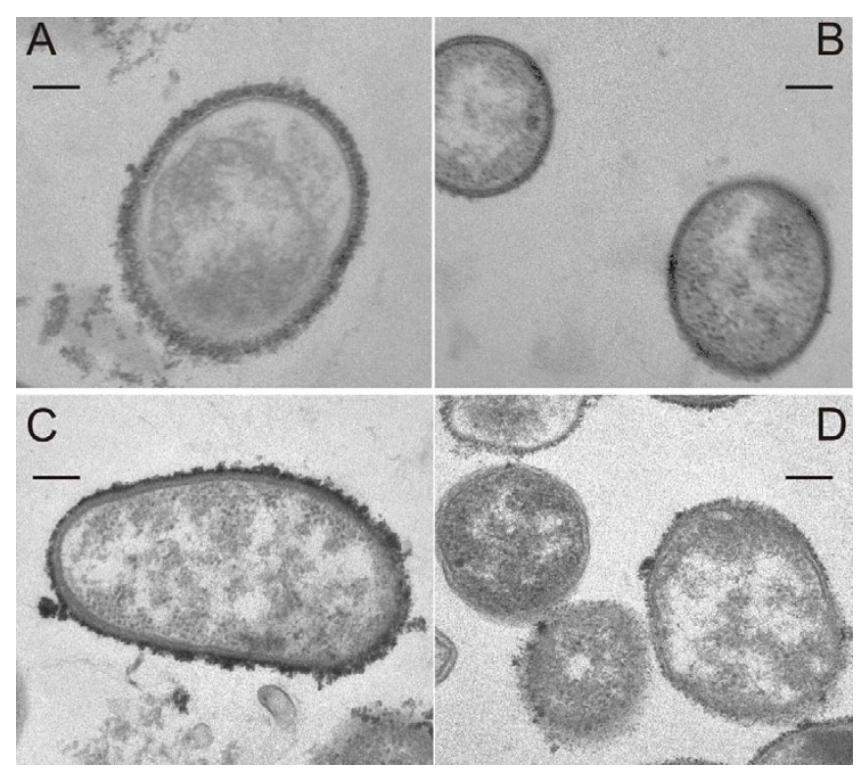

\section{Figure 5}

Thin sections of $V$. cholerae NRT36S and its translucent mutants stained with polycationic ferritin. (A) NRT36S; (B) TR3; (C) TR296; (D) TRI7. Bar, 200 nm.

recent report that an $\mathrm{ABC}$ transporter system was involved in the transportation of hetero-polysaccharides in the Oantigen of E. coli O52 [29]. Our results may be another case where an $\mathrm{ABC}$ transporter system was involved in the transportation of a hetero-polysaccharide.

\section{Sharing of the same region by CPS and LPS}

The $\mathrm{O}$-antigen genes had been identified for several serogroups in $V$. cholerae, including $\mathrm{O} 1, \mathrm{O} 139, \mathrm{O} 22$ and $\mathrm{O} 37$ $[3,4,6,7,23]$. In these serogroups, the gene cluster for $\mathrm{O}$ antigen biogenesis all resided between the genes gmhD and rjg. In our study of $V$. cholerae NRT36S genome, there was a gene cluster identified as the LPS core biogenesis region upstream of the $g m h D$ gene (data not shown). There was also another gene cluster in the genome that was identified as the rugose-associated exopolysaccharide biosynthesis region (data not shown). The homologs of these genes were recognized as exopolysaccharide genes that related to the rugose phenotype in $V$. cholerae $\mathrm{O} 1 \mathrm{El}$ Tor [30]. Besides these regions, i. e., the LPS core genes and the rugose exopolysaccharide genes, there were no other significant gene clusters for polysaccharide synthesis in the genome of $V$. cholerae NRT36S. All of this evidence supported the conclusion that the CPS region, i.e. the region between $g m h D$ and rjg genes, is indeed also the Oantigen gene cluster. The immuno blot showed that the LPS had been altered in the non-encapsulated mutants. That not only confirmed the sharing of the CPS and LPS region, but also indicated that some genes may be shared by the biogenesis of the two polysaccharide structures. A potential test of this suggestion would be to determine whether the genes other than those encoding rhamnose synthesis involved in the O6 LPS serotype are related to the genes in NRT36S since the two organisms have LPS and capsule structures that are nearly identical.

The known O-antigen and now CPS regions from $V$. cholerae shared remarkably few genes. The sequences between gmhD and rjg are known for O1, O22, O37, O139 and now $\mathrm{O} 31$ (Figure 7). Only the three genes are found in all five sequences $w z m$, galE and $w b e W$. Our mutagensis experiments revealed that both $w z m$ and galE were essential for capsule production, but enigmatically $\mathrm{O} 1$, although it has the genes, it does not have a capsule. Galactose is part of the polysaccharide backbone in $\mathrm{O} 139$ for both the LPS and the CPS, but it is not part of the backbone in either O1 LPS or O31 CPS. The structure of O37 is not known. Of note, the $\mathrm{O} 31$ region is the first not to contain an IS element.

CPS and O-antigen shared the same genetic locus in $V$. cholerae NRT36S. This differs from the organization of CPS and O-antigen gene clusters in E. coli. In E. coli, CPS gene clusters and the $\mathrm{O}$-antigen gene clusters are different [9]. The CPS genes from other gram-negative bacteria including Haemolyticus influenza, Salmonella typhi and Neisseria meningitidis have been cloned and characterized [31-36]. The organizations of most of them resemble $E$. coli. No LPS genes have been reported to embed inside the CPS gene cluster for these species except in N. meningitides. In $N$. meningitides group $\mathrm{B}$, the mutations of two CPS biosynthesis genes (synX or synC) and another gene next to the CPS region, galE gene, were shown to affect the lipooligosaccharide structure [33,36]. The CPS and Oantigen in group $4 \mathrm{E}$. coli consist of the same molecule. This arrangement is also seen in $V$. cholerae O139 where CPS and O-antigen are encoded by the same genetic locus and have identical repeating subunits. NRT36S is an O31 serogroup. Kondo's group found that the LPS of O31 in $V$. cholerae contains L-glycero-D-mannoheptose, glucose, fructose, galactose, glucosamine and an unknown amino sugar A2 [37]. L-rhamnose was not found in the LPS, while our study found L-rhamnose in the CPS, suggested that CPS and LPS are two distinct structures in $V$. cholerae NRT36S. The antiserum against NRT36S detected LPS but not the capsule, again suggested that the O-antigen and CPS were two different entities. Our finding represents a new type of genetic organization of polysaccharide genes and raises a question of differential regulation of the genes for expression of capsule and $\mathrm{O}$-antigen polysaccharides.

\section{Conclusion}

The genes for bacterial surface polysaccharide biogenesis were typically found in a cluster with an atypical GC content compared to the rest of the genome [38]. It had been 

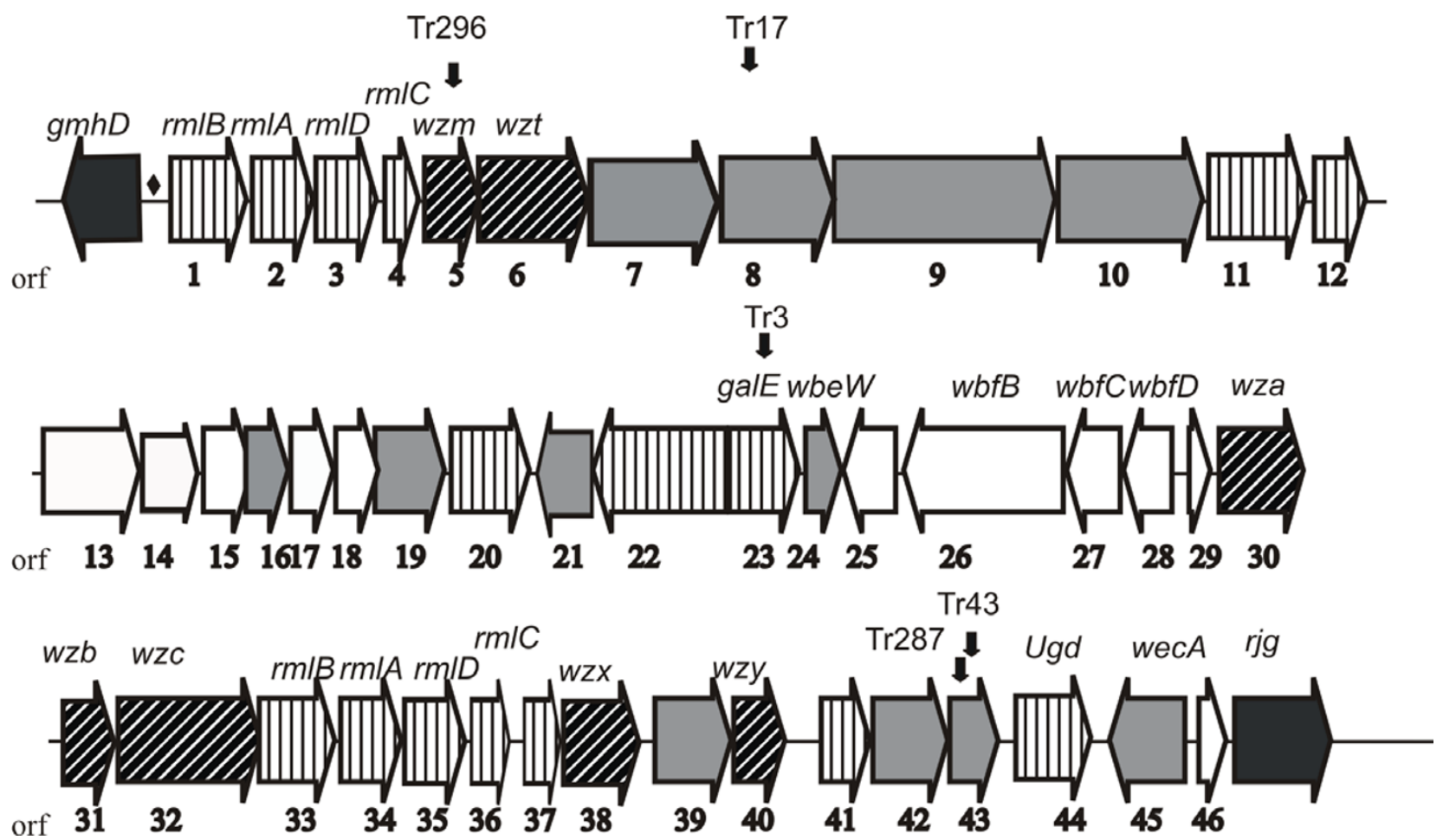

Figure 6

Map of the CPS/O-antigen region of V. cholerae NRT 36s. JUMPstart site is indicated by a diamond. Transposon insertion sites are indicated by black arrows. Design patterns of open reading frames indicate different classes of genes: vertical lines, pathway genes; diagonal lines, processing and transportation genes; grey box, glycosyltransferase; white box, functions not clear.

suggested that bacteria could convert to a new serogroup by acquiring a new $\mathrm{O}$-antigen biogenesis region. There was abundant evidence that $V$. cholerae $\mathrm{O} 139$ arose from an $\mathrm{O} 1$ strain by receiving a new $\mathrm{O}$-antigen gene cluster $[5,39,40]$. The sharing of CPS and O-antigen in V. cholerae, as indicated in our findings, makes this region one interchangeable unit. It is possible that $V$. cholerae can acquire a new gene cluster and give rise to a new strain with an O-antigen and K-antigen at the same time, both unrecognizable to the host immune system. This, in turn, may be a key element in its ability to survive, permitting rapid emergence of new strains that can escape immunologic detection by host populations.

\section{Methods}

\section{Bacterial strains and culture conditions}

$V$. cholerae NRT36S is an isolate originally cultured from a Japanese patient with travelers' diarrhea. It is serogroup O31, cholera toxin negative and produces a heat stable enterotoxin NAG-ST [41]. When fed to volunteers this strain caused diarrhea, including, in one patient, a 5.3liter diarrheal purge [5]. Wild type $V$. cholerae NRT36S produces a capsule [19]. This strain is resistant to polymyxin $\mathrm{B}$ but sensitive to kanamycin.
Transposon mini-Km2 was carried in the plasmid putKm-

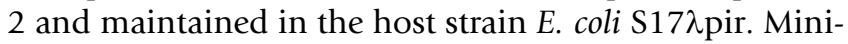
$\mathrm{Km} 2$ was found to randomly transpose into the genome of the recipient strain with a single transposition. Mini$\mathrm{Km} 2$ encodes a gene for kanamycin resistance. $[42,43]$

Cultures were maintained in L broth with $15 \%$ glycerol at $-70^{\circ} \mathrm{C}$. Bacteria were cultured in broth or agar at $37^{\circ} \mathrm{C}$ unless otherwise stated. Appropriate antibiotics were added in concentrations: $50 \mathrm{mg} / \mathrm{ml}$ kanamycin, 50 unit/ $\mu$ l polymyxin $\mathrm{B}$.

\section{Isolation and purification of CPS}

Frozen stock of NRT36S was streaked for isolation on L agar in 150-mm Petri dishes and incubated overnight. A single bacterial colony from the plate was inoculated into $10 \mathrm{ml}$ of L-broth for $18 \mathrm{~h}$ of growth. One $\mathrm{ml}$ of the culture was then inoculated into 1-liter L-broth and incubated overnight. Bacterial cells from eight 1-liter batches of culture were pelleted at $10,000 \mathrm{~g}$ and resuspended in $120 \mathrm{ml}$ of 0.5X phosphate-buffered saline (PBS) $\mathrm{pH} 7.5$ and shaken at $200 \mathrm{rpm}$ on a rotary shaker for $2 \mathrm{~h}$ at room temperature. The bacterial suspensions were centrifuged to remove cell debris at $16,000 \mathrm{~g}$ for 20 minutes at $4{ }^{\circ} \mathrm{C}$ and 
Table 6: Genes in the CPS/O-antigen biogenesis region

\begin{tabular}{|c|c|c|c|c|c|}
\hline orf & symbol & annotated & \%AA identity/positive & species & E-Value \\
\hline$\underline{0}$ & gmhD & ADP-L-glycero-D-mannoheptose-6-epimerase & $99 / 99$ & Vibrio cholerae & I.00E-180 \\
\hline 1 & $r m / B$ & DTDP-D-glucose-4,6-dehydratase & $99 / 99$ & Vibrio cholerae & 0 \\
\hline$\underline{2}$ & $r m l A$ & Glucose-I-phosphate thymidylyltransferase & $100 / 100$ & Vibrio cholerae & I.00E-167 \\
\hline$\underline{3}$ & $r m I D$ & DTDP-6-deoxy-L-mannose-dehydrogenase & $99 / 99$ & Vibrio cholerae & $1.00 \mathrm{E}-169$ \\
\hline$\underline{4}$ & $r m / C$ & DTDP-6-deoxy-D-glucose-3,5-epimerase & $100 / 100$ & Vibrio cholerae & I.00E-104 \\
\hline$\underline{5}$ & wzm & $A B C$ transporter system integral membrane protein & $55 / 77$ & Raoultella terrigena & I.00E-8I \\
\hline$\underline{6}$ & wzt & $\mathrm{ABC}$ transporter system ATPase component & $43 / 59$ & Nitrosospira multiformis & $8.00 \mathrm{E}-86$ \\
\hline$\underline{7}$ & & glycosyltransferase & $32 / 49$ & Rubrobacter xylanophilus & $2.00 \mathrm{E}-24$ \\
\hline$\underline{8}$ & & glycosyltransferase & $40 / 57$ & Nitrosospira multiformis & $1.00 \mathrm{E}-125$ \\
\hline$\underline{9}$ & & glycosyltransferase & $4 \mid / 57$ & Burkholderia fungorum & I.IOE-127 \\
\hline$\underline{10}$ & & glycosyltransferase & $38 / 56$ & Burkholderia sp. & $8.00 \mathrm{E}-56$ \\
\hline$\underline{11}$ & & dTDP-glucose-4-keto-6-deoxy-D-glucose reductase & $39 / 64$ & Actinobacillus actinomycetemcomitans & $4.00 \mathrm{E}-21$ \\
\hline$\underline{12}$ & & probable acetyl transferase by domain & $30 / 46$ & Cellulophaga sp. & 0.049 \\
\hline$\underline{13}$ & & hypothetical protein & & & \\
\hline$\overline{14}$ & & 3-hydroxybutyryl-CoA dehydrogenase & $48 / 68$ & Pseudoalteromonas haloplanktis & $2.00 \mathrm{E}-70$ \\
\hline$\underline{15}$ & & Hypothetical protein & & & \\
\hline$\underline{16}$ & & glycosyltransferase & $27 / 44$ & Syntrophus aciditrophicus & $9.00 \mathrm{E}-06$ \\
\hline$\underline{17}$ & & Hypothetical protein & & & \\
\hline$\underline{18}$ & & hypothetical protein & & & \\
\hline$\underline{19}$ & & putative glycosyl transferase & $55 / 69$ & Pseudomonas fluorescens & $8.00 E-97$ \\
\hline$\underline{20}$ & & UDP-N-acetylglucosamine 2-epimerase & $67 / 82$ & Yersinia intermedia & I.00E-147 \\
\hline$\underline{21}$ & & glycosyltransferase & $96 / 97$ & Vibrio cholerae & $2.00 \mathrm{E}-93$ \\
\hline$\underline{22}$ & & nucleoside-diphosphate sugar epimerase & $99 / 99$ & Vibrio cholerae & 0 \\
\hline$\underline{23}$ & galE & UDP-glucose 4-epimerase VC0262 & $98 / 99$ & Vibrio cholerae & 0 \\
\hline$\underline{24}$ & wbeW & galactosyl-transferase VC0263 & $99 / 99$ & Vibrio cholerae & $4.00 \mathrm{E}-91$ \\
\hline$\underline{25}$ & & Trypsin-like serine proteases & $96 / 97$ & Vibrio cholerae & I.00E-123 \\
\hline$\underline{26}$ & $w b f B$ & hypothetical protein & $99 / 99$ & Vibrio cholerae & 0 \\
\hline$\underline{27}$ & $w b f C$ & hypothetical protein wbfC, periplasmic & $97 / 97$ & Vibrio cholerae & $1.00 \mathrm{E}-|4|$ \\
\hline$\underline{28}$ & wbfD & hypothetical protein wbfD & $98 / 98$ & Vibrio cholerae & $1.00 \mathrm{E}-112$ \\
\hline$\underline{29}$ & & hypothetical protein & $52 / 58$ & Vibrio cholerae & $6.00 \mathrm{E}-12$ \\
\hline$\underline{30}$ & $w z a$ & $\begin{array}{c}\text { Periplasmic protein involved in capsular polysaccharide } \\
\text { export }\end{array}$ & $67 / 82$ & Vibrio splendidus & $1.00 \mathrm{E}-|5|$ \\
\hline$\underline{31}$ & $w z b$ & Protein-tyrosine-phosphatase & $75 / 88$ & Vibrio vulnificus & $6.00 \mathrm{E}-59$ \\
\hline$\underline{32}$ & $w z c$ & Putative tyrosine-protein kinase $\mathrm{Wzc}$ & $75 / 87$ & Vibrio vulnificus & 0 \\
\hline$\underline{33}$ & $r m / B$ & dTDP-D-glucose-4,6-dehydratase & $98 / 98$ & Vibrio cholerae & 0 \\
\hline$\underline{34}$ & $r m I A$ & glucose-I-phosphate thymidylyltransferase & $100 / 100$ & Vibrio cholerae & I.00E-167 \\
\hline$\underline{35}$ & $r m / D$ & dTDP-6-deoxy-L-mannose-dehydrogenase & $99 / 99$ & Vibrio cholerae & $1.00 \mathrm{E}-169$ \\
\hline$\underline{36}$ & $r m / C$ & DTDP-6-deoxy-D-glucose-3,5-epimerase & $92 / 94$ & Vibrio cholerae & $1.00 \mathrm{E}-88$ \\
\hline$\underline{37}$ & & O-acetyltransferase & $38 / 58$ & Enterococcus faecalis & $8.00 \mathrm{E}-17$ \\
\hline$\underline{38}$ & $w z x$ & O-antigen translocase & $30 / 48$ & Pelodictyon luteolum & $2.00 \mathrm{E}-39$ \\
\hline$\underline{39}$ & & glucosyltransferase & $34 / 53$ & Pseudoalteromonas tunicate & I.00E-39 \\
\hline$\underline{40}$ & wzy & Putative saccharide polymerase & & & \\
\hline$\underline{41}$ & & Putative sugar acetyltransferase & $51 / 72$ & COGOI I0, Cytophaga hutchinsonii & $7.00 \mathrm{E}-43$ \\
\hline$\underline{42}$ & & glycosyltransferase & $29 / 53$ & Cytophaga hutchinsonii & $5.00 \mathrm{E}-4 \mathrm{I}$ \\
\hline$\underline{43}$ & & Rhamnosyltransferase & $66 / 77$ & Shewanella sp. & $1.00 \mathrm{E}-1 \mathrm{I} 3$ \\
\hline$\underline{44}$ & Ugd & UDP-glucose 6-dehydrogenase & $81 / 90$ & Vibrio sp. & 0 \\
\hline$\underline{45}$ & wecA & $\begin{array}{l}\text { Undecaprenylphosphate } \mathrm{N} \text {-acetylglucosamine I- } \\
\text { phosphate transferase }\end{array}$ & $96 / 99$ & Vibrio cholerae & I.00E- 157 \\
\hline$\underline{46}$ & & Hypothetical protein & $96 / 96$ & Vibrio cholerae & $2.00 \mathrm{E}-63$ \\
\hline$\underline{47}$ & rjg & $\begin{array}{l}\text { Predicted exonuclease of the beta-lactamase fold } \\
\text { involved in RNA processing }\end{array}$ & $98 / 99$ & Vibrio cholerae & 0 \\
\hline
\end{tabular}



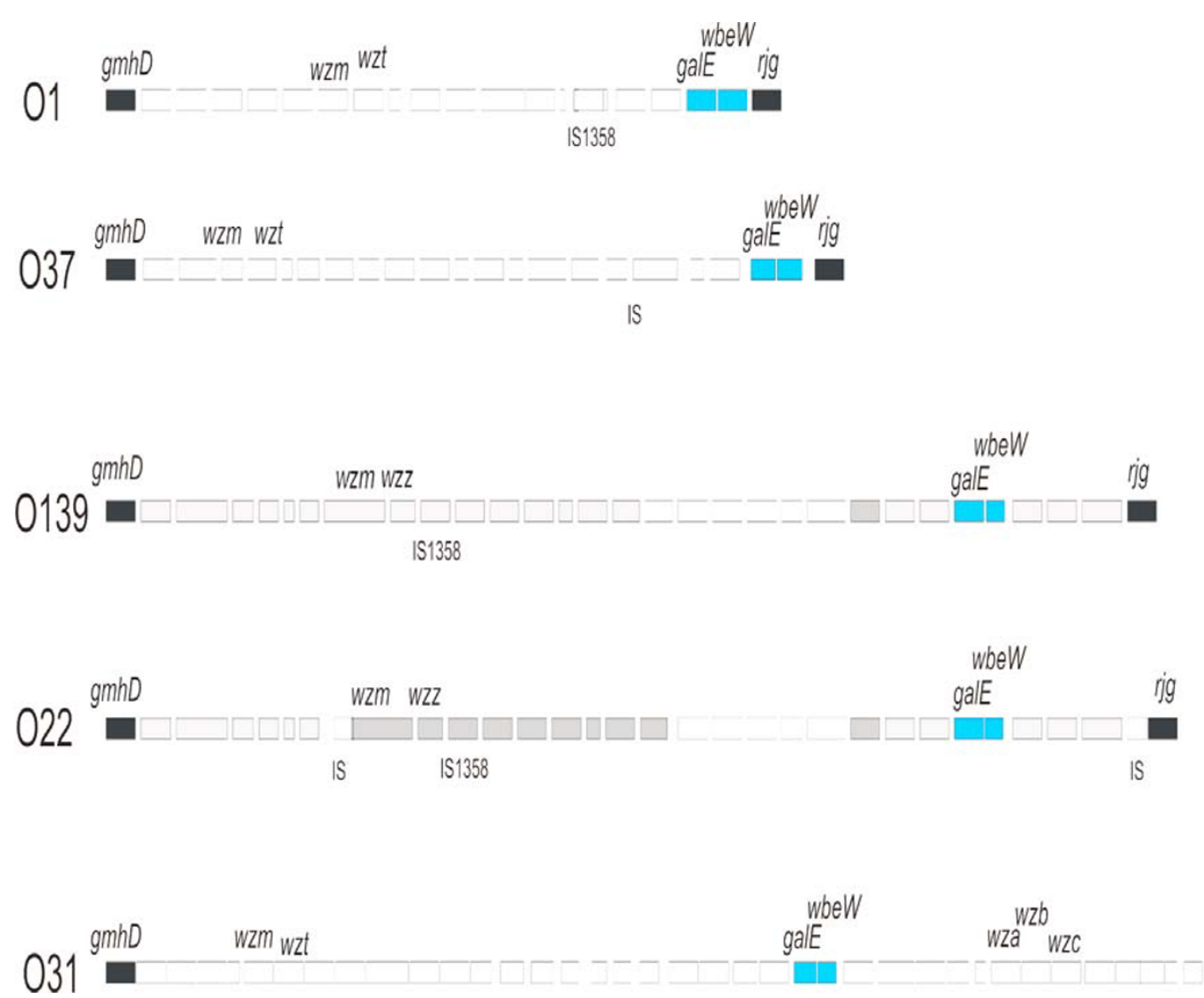

Figure 7

Pictorial representation of the genes in the LPS/CPS regions of OI, O37, O22, OI39 and O3I Vibrio cholerae. The galE and wbeW genes found in common between all five sequences are marked in blue. The housekeeping genes gmhD and rjg that delineate the region are marked in black. The genes in common between 022 aand OI39 are marked in grey. The transport genes and the IS elements are labeled. The unlabeled genes represented by white boxes are not found in common across the regions.

the supernatant dialyzed with multiple changes of distilled water and concentrated two fold by ultra filtration (100,000-nominal-molecular-weight stirred cell; Amicon, Beverly, Mass). The retentates were then ultra centrifuged at $154,000 \mathrm{~g}$ for $2 \mathrm{~h}$ at $20^{\circ} \mathrm{C}$ and the supernatants were removed and digested with RNase A (100 ug/ml) and DNase 1 ( $50 \mathrm{ug} / \mathrm{ml}$ plus $1 \mathrm{mM} \mathrm{MgCl}$ ) for $2 \mathrm{~h}$ followed by a $3 \mathrm{~h}$ digestion with proteinase $\mathrm{K}(250 \mathrm{ug} / \mathrm{ml})$ and phenolchloroform extraction. The aqueous layer was dialyzed as described above, and the resultant sample was lyophilized. Purity of the CPS was assessed by bicinchoninic acid protein assay (MicroBCA, Pierce Chemical Co., Rockford Ill.), and Limulus amoebocyte lysate assay (Sigma Chemical Co., St. Louis, Mo.) and by NMR.

\section{Deacylation and preparation of samples for NMR}

A sample of $15 \mathrm{mg}$ of CPS in $0.6 \mathrm{ml} \mathrm{D}_{2} \mathrm{O}$ was subjected to deacylation by $0.3 \mathrm{M}$ ammonium hydroxide for 6 days at $25 \mathrm{C}$. The $1 \mathrm{D}^{1} \mathrm{H}$ spectrum was monitored daily and the sample was lyophilized, exchanged with $99.9 \% \mathrm{D}_{2} \mathrm{O}$ and made up with $0.6 \mathrm{ml}$ pure $\mathrm{D}_{2} \mathrm{O}$ (de-O-acetyl polysaccharide). A second sample was prepared with milder base treatment in $0.03 \mathrm{M}$ ammonium hydroxide for 5 days at $4^{\circ} \mathrm{C}$ (mono-O-acetyl polysaccharide). For detection of amide protons, a sample was subjected to deacylation (without $\mathrm{D}_{2} \mathrm{O}$ exchange) and made up with $0.6 \mathrm{ml} 90: 10$ (v/v) $\mathrm{H}_{2} \mathrm{O}: \mathrm{D}_{2} \mathrm{O}$.

\section{NMR spectroscopy}

NMR experiments were performed on Bruker $500 \mathrm{MHz}$ DRX AVANCE spectrometer equipped with cryoprobe, with a Bruker $800 \mathrm{MHz}$ DMX AVANCE spectrometer. All Bruker data were processed with NMRPipe and NMRDraw under Linux. All spectra were taken at $50^{\circ} \mathrm{C}$ due to dynamic properties of the polysaccharide. The following experiments were recorded using standard sequences: 1D: ${ }^{1} \mathrm{H}$ spectrum, ${ }^{13} \mathrm{C}$ spectrum; 2D: ge-DQF-COSY (E/A), geTOCSY (DIPSI-2 mixing times 30 and $70 \mathrm{~ms}, \mathrm{E} / \mathrm{A}$ ), geNOESY (mixing time $50 \mathrm{~ms}$ ), ge-HSQC (decoupled, E/A), ge-HMBC (long-range evolution time $30 \mathrm{~ms}$, magnitude 
mode), HSQMBC (long-range evolution time $15 \mathrm{~ms}$ ), geHMQC-COSY (E/A), ge-HSQC-TOCSY (decoupled, DIPSI-2 mixing time $30 \mathrm{~ms}, \mathrm{E} / \mathrm{A})$. Also the direct ${ }^{31} \mathrm{P}$ and 1D ${ }^{31} \mathrm{P}$ spin-echo difference spectra were measured. For detection of amide protons, the following experiments were recorded on a sample of mono-O-acetyl polysaccharide in $90 \% \mathrm{H}_{2} \mathrm{O} / 10 \% \mathrm{D}_{2} \mathrm{O}$ solution: $1 \mathrm{D}$ : ${ }^{1} \mathrm{H}$ spectrum; 2D: ge-TOCSY (DIPSI-2 mixing time $50 \mathrm{~ms}$, E/A, WATERGATE 3-9-19 combined with presaturation). All chemical shifts are reported relative to internal standard acetone set to $2.225 \mathrm{ppm}\left({ }^{1} \mathrm{H}\right)$ and $30.1 \mathrm{ppm}\left({ }^{13} \mathrm{C}\right)$.

\section{Methylation analysis}

Methylation analysis was done by means of gas chromatography-mass spectroscopy of partially methylated alditol acetates (performed at Complex Carbohydrate Research Center at University of Georgia). Two hundred $\mu \mathrm{g}$ aliquot of the sample was permethylated following Ciucanu and Kerek [44]. The sample was treated with $\mathrm{NaOH}$ and methyl iodide in dry DMSO. The permethylation was repeated twice in order to completely methylate the polymer. Following the permethylation, the sample was hydrolyzed using $2 \mathrm{M} \mathrm{HCl}$ for 3 hours at $100^{\circ} \mathrm{C}$. Then it was reduced with $\mathrm{NaBD}_{4}$ and acetylated using acetic anhydride/pyridine. The resulting partially methylated alditol acetates were analyzed on HP 5890 GC connected to mass selective detector in ESI ionization mode. The separation was done on $30 \mathrm{~m}$ Supelco DB-1 2330 bonded phase fused silica capillary column ( $0.25 \mathrm{~mm}$ ID).

\section{Transposon mutagenesis}

Conjugations were performed between $V$. cholerae NRT36S as the recipient strain and E. coli S17 $\lambda$ pir/putKm2 as the donor strain. Ten $\mu$ l overnight culture of $V$. cholerae NRT36S was spotted on LB agar and let dry, $10 \mu$ lovernight culture of $S 17 \lambda$ pir/putKm 2 was then spotted on top. After overnight incubation at room temperature, the mixture was re-suspended in $1 \mathrm{ml}$ of LB broth; $50 \mu \mathrm{l}$ of the suspension was plated onto LB agar with kanamycin and polymyxin B to select for $V$. cholerae mutants.

\section{DNA analysis}

DNA flanking the transposon in the mutants was amplified and sequenced by a modified inverse PCR protocol [45]. Genomic DNA was isolated with PrepMan ${ }^{\text {тм }}$ (Applied Biosystems) according to the manufacturer's instruction. Two $\mu \mathrm{l}$ genomic DNA of the above preparation was digested with 5 units of Nla III (New England Biolab) in a $20 \mu \mathrm{l}$ reaction overnight followed by denaturing at $65^{\circ} \mathrm{C}$ for 15 minutes. Two $\mu \mathrm{l}$ of the digested DNA was self-ligated with 5 units of T4 DNA ligase (Invitrogen) in a $10 \mu \mathrm{l}$ reaction. One $\mu \mathrm{l}$ of this solution was used as PCR template. Two primers were designed to anneal to the transposon mini-Km2, pointing outwards to amplify the flanking sequence of the mutant genomic DNA. The sequences of the primers are, L8 (Reverse), GTACCGAGCTCGAATTCGGCCTAG; and L9 (forward), GGAGAAAACTCACCGAGGCAGTTC. PCR was performed in a $30 \mu \mathrm{l}$ reaction containing $100 \mu \mathrm{M}$ of each dNTP, $1.5 \mathrm{mM}$ of $\mathrm{MgCl}_{2}, 1 \mathrm{x}$ PCR buffer (Invitrogen) and 1 unit of Taq DNA polymerase (Invitrogen). PCR products were purified with the Multiscreen PCR plates (Millipore) and sequenced using the BigDye ${ }^{\circledast}$ Terminator v3.1 Cycle Sequencing Kit (Applied Biosystems). The resulting fragments were separated and recorded in an ABI $3730 \times 1$ automatic sequencer (Applied Biosystems). DNA sequence was then analyzed by the PHRED, PHRAP and CONSED software [46-48].

\section{Complement resistance and EM}

Translucent colonies were challenged with complement in human serum as previously described [19]. EM was also performed as described [19].

\section{SEC}

Capsule preps were analyzed by SEC using a Beckman Coulter 32 Karat HPLC, with TSK gel column (JOSOHAAS; G3000SWxL; $10 \mathrm{um} ; 30 \mathrm{~cm} \times 7.5 \mathrm{~mm}$ ), and detected at $200 \mathrm{~nm}$ wavelength. Purified NRT36S capsule was the same sample as used for NMR and methylation analyses. Capsule preps were prepared as followed: $10^{9}$ cells were harvested into 0.5X PBS and shaken for 2 hours in a rotary shaker at $250 \mathrm{rpm}$ followed by centrifuge at $12000 \mathrm{~g}$ for $20 \mathrm{~min}$. The supernatant was treated with Dnase I and Rnase, followed by protease. The supernatant was then extracted with phenol-chloroform and precipitated with ethanol. The pellet was resuspended in water and $1 / 3$ of the amount was loaded.

\section{Immuno blotting}

Immuno blotting was performed as described [23]. Circa $5 \times 10^{6}$ bacterial cells were treated with DNase I, RNase followed by protease. Washed whole cell lysates were run on $16 \%$ SDS-polyacrylamide gel and transferred to Immun-Blot PVDF membrane (BioRad, Hercules, CA). Blots were blocked in PBS containing 3\% non-fat dry milk and then incubated for $1 \mathrm{~h}$ in 1:1000 rabbit antiserum specific for $V$. cholerae NRT36S. The blots were washed three times with PBS and incubated with alkaline phosphatase-conjugated goat anti-rabbit immunoglobin G (Sigma) at 1:10,000 in PBS for $1 \mathrm{~h}$. The blot was washed five times with PBS and developed with Western Blue colorimetric detection solution (Promega).

\section{Sequencing of V. cholerae NRT36S genome}

The genome of NRT36S was sequenced by the company 454 Life Science (454 Life Science, Branford, CT) [45]. The contigs of the draft genome was compared and aligned to the fully sequenced genome of $V$. cholerae N16961 [24] by Blastn [49]. Gaps between contigs were filled only for the 
capsule biogenesis region, which contained the genes identified by transposon mutagenesis. Primers were designed for PCR to amplify the fragments of the gaps. PCR products were then sequenced.

\section{Sequence analysis and annotation}

Open reading frames were predicted by the program GLIMMER[48] using the DasSarma Laboratory Autoannotation Pipeline (DLAP) (http://halo.umbi.umd.edu/. DasSarma et al., manuscript in preparation). The settings in Glimmer were as in default, with the minimum gene size to be 90 bps and overlapping to be less than 30 bps. BlastX program [49]was used for a similarity search against the protein database in NCBI. We also used Artemis [50] to edit and confirm the results of GLIMMER.

\section{Abbreviations}

CPS - capsule polysaccharide, LPS - liposaccharide, PCR - polymerase chain reaction, PBS - phosphate buffered saline, SDS - sodium dodeceyl sulfate, SEC size exclusion chromatography, HPLC high pressure liquid chromotagraphy, EM - electron microscopy, NMR nuclear magnetic resonance, HSQC - heteronuclear single quantum correlation, COSY - correlation spectroscopy, NOESY nuclear Overhauser spectroscopy, TOCSY - total correlation spectroscopy, HMBC - heteronuclear multiple bond coherence

\section{Authors' contributions}

YC performed bacteriological, genetic and EM studies, helped with the experimental design and drafted the manuscript. JA, $\mathrm{PB}, \mathrm{CAB}$ performed the capsule isolation, NMR and gas chromatography studies. AA was involved in the mutagenesis studies. PP was involved in the EM and antibody studies. JAJ was involved in the microbiological experiments and experimental design. JGM was involved in the experimental design. OCS was involved in the sequencing and annotation and experimental design. All authors read and approved the final manuscript.

\section{Acknowledgements}

We would like to thank Dr. Shiladitya DasSarma and Beenish Bhatia for the kindly helping in annotating the genome of $V$. cholerae NRT36S using their server and their script to automate the annotation process. We also thank the company 454 life science for sequencing the genome of $V$. cholerae NRT36S and the Complex Carbohydrate Research Center at the Univ. of Georgia for carbohydrate analyses as supported by DOE Grant DE-FG0993ER-20097. We acknowledge support by NSF Grant MCB--2 I 2702 and of $\mathrm{NIH}$ grant GM-6079I.

\section{References}

I. Kaper JB, Morris JG Jr., Levine MM: Cholera. Clin Microbiol Rev I995, 8(I):48-86.

2. Holmgren J, Svennerholm AM: Mechanisms of disease and immunity in cholera: a review. J Infect Dis 1977, 136 Suppl:SI05-12.

3. Li M, Shimada T, Morris JG Jr., Sulakvelidze A, Sozhamannan S: Evidence for the emergence of non-OI and non-OI39 Vibrio cholerae strains with pathogenic potential by exchange of 0 antigen biosynthesis regions. Infect Immun 2002, 70(5):244l-2453.

4. Manning PA, Heuzenroeder MW, Yeadon J, Leavesley DI, Reeves PR, Rowley D: Molecular cloning and expression in Escherichia coli K-I 2 of the $O$ antigens of the Inaba and Ogawa serotypes of the Vibrio cholerae $O I$ lipopolysaccharides and their potential for vaccine development. Infect Immun 1986, 53(2):272-277.

5. Morris JG Jr., Takeda T, Tall BD, Losonsky GA, Bhattacharya SK, Forrest $B D$, Kay BA, Nishibuchi M: Experimental non-O group I Vibrio cholerae gastroenteritis in humans. J Clin Invest 1990, 85(3):697-705.

6. Yamasaki S, Shimizu T, Hoshino K, Ho ST, Shimada T, Nair GB, Takeda $Y$ : The genes responsible for O-antigen synthesis of vibrio cholerae OI39 are closely related to those of vibrio cholerae O22. Gene 1999, 237(2):321-332.

7. Sozhamannan S, Deng YK, Li M, Sulakvelidze A, Kaper JB, Johnson JA, Nair GB, Morris JG Jr.: Cloning and sequencing of the genes downstream of the wbf gene cluster of Vibrio cholerae serogroup 0139 and analysis of the junction genes in other serogroups. Infect Immun 1999, 67( I 0):5033-5040.

8. Johnson JA, Joseeph A, Panigrahi P, Morris JG: Frequency of encapsulated versus unencapsulated strains of non-OI Vibrio cholerae isolated from patients with septicemia of diarrhea, of from environmental strains. In American Society for Microbiology annual meeting New Orleans, Louisiana ; 1992.

9. Whitfield C, Roberts IS: Structure, assembly and regulation of expression of capsules in Escherichia coli. Mol Microbiol 1999. 3 I(5): | 307-1319.

10. Cox AD, Perry MB: Structural analysis of the O-antigen-core region of the lipopolysaccharide from Vibrio cholerae OI39. Carbohydr Res 1996, 290(I):59-65.

II. Cox AD, Brisson JR, Varma V, Perry MB: Structural analysis of the lipopolysaccharide from Vibrio cholerae O 139. Carbohydr Res 1996, 290(I):43-58.

12. Knirel YA, Widmalm G, Senchenkova SN, Jansson PE, Weintraub A: Structural studies on the short-chain lipopolysaccharide of Vibrio cholerae Ol39 Bengal. Eur J Biochem 1997, 247( I):402-4I0.

13. Simpson LM, White VK, Zane SF, Oliver JD: Correlation between virulence and colony morphology in Vibrio vulnificus. Infect Immun 1987, 55(I):269-272.

14. Chatzidaki-Livanis M, Jones MK, Wright AC: Genetic Variation in the Vibrio vulnificus Group I Capsular Polysaccharide Operon. J Bacteriol 2006, I 88(5): 1987-1998.

15. Wright AC, Powell JL, Kaper JB, Morris JG Jr.: Identification of a group I-like capsular polysaccharide operon for Vibrio vulnificus. Infect Immun 200I, 69( I I):6893-690I.

16. Smith $A B$, Siebeling RJ: Identification of genetic loci required for capsular expression in Vibrio vulnificus. Infect Immun 2003, 7I(3): $1091-1097$.

17. Structural analysis of carbohydrates [http:// www.casper.organ.su.se/sop/sop7.html]

18. Bergstrom N, Nair GB, Weintraub A, Jansson PE: Structure of the O-polysaccharide from the lipopolysaccharide from Vibrio cholerae O6. Carbohydr Res 2002, 337(9):813-817.

19. Johnson JA, Panigrahi P, Morris JG Jr.: Non-Ol Vibrio cholerae NRT36S produces a polysaccharide capsule that determines colony morphology, serum resistance, and virulence in mice. Infect Immun 1992, 60(3):864-869.

20. Panigrahi $P$, Morris JG Jr: Identification of non-OI Vibrio cholerae adherence proteins using a Caco-2 cell in vitro system. 93rd General Meeting, American Society for Microbiology, Atlanta, Georgia 1993.

21. Chen Y, Johnson JA, Pusch GD, Morris JG Jr., Stine OC: The genome of non-OI Vibrio cholerae NRT36S demonstrates the presence of pathogenic mechanisms that are distinct from OI Vibrio cholerae. Infect Immun 2007.

22. National Microbial Pathogen Database Resource [http:// www.nmpdr.org]

23. Comstock LE, Johnson JA, Michalski JM, Morris JG Jr., Kaper JB: Cloning and sequence of a region encoding a surface polysaccharide of Vibrio cholerae OI39 and characterization of the insertion site in the chromosome of Vibrio cholerae $\mathrm{OI}$. Mol Microbiol 1996, I9(4):815-826. 
24. Heidelberg JF, Eisen JA, Nelson WC, Clayton RA, Gwinn ML, Dodson RJ, Haft DH, Hickey EK, Peterson JD, Umayam L, Gill SR, Nelson KE, Read TD, Tettelin H, Richardson D, Ermolaeva MD, Vamathevan J, Bass S, Qin H, Dragoi I, Sellers P, McDonald L, Utterback T, Fleishmann RD, Nierman WC, White O, Salzberg SL, Smith HO, Colwell RR, Mekalanos J], Venter JC, Fraser CM: DNA sequence of both chromosomes of the cholera pathogen Vibrio cholerae. Nature 2000, 406(6795):477-483.

25. Hobbs M, Reeves PR: The JUMPstart sequence: a 39 bp element common to several polysaccharide gene clusters. Mol Microbiol 1994, I2(5):855-856.

26. Li Q, Hobbs M, Reeves PR: The variation of dTDP-L-rhamnose pathway genes in Vibrio cholerae. Microbiology 2003, I49(Pt 9):2463-2474.

27. Cserzo M, Bernassau JM, Simon I, Maigret B: New alignment strategy for transmembrane proteins. J Mol Biol 1994, 243(3):388-396.

28. Reid AN, Whitfield C: functional analysis of conserved gene products involved in assembly of Escherichia coli capsules and exopolysaccharides: evidence for molecular recognition between Wza and Wzc for colanic acid biosynthesis. J Bacteriol 2005, 187( I 5):5470-548I.

29. Feng L, Senchenkova SN, Yang J, Shashkov AS, Tao J, Guo H, Cheng J, Ren Y, Knirel YA, Reeves PR, Wang L: Synthesis of the heteropolysaccharide $O$ antigen of Escherichia coli 052 requires an ABC transporter: structural and genetic evidence. J Bacteriol 2004, 186(I4):4510-45।9.

30. Yildiz FH, Liu XS, Heydorn A, Schoolnik GK: Molecular analysis of rugosity in a Vibrio cholerae OI El Tor phase variant. Mol Microbiol 2004, 53(2):497-5I5.

31. Frosch M, Weisgerber C, Meyer TF: Molecular characterization and expression in Escherichia coli of the gene complex encoding the polysaccharide capsule of Neisseria meningitidis group B. Proc Natl Acad Sci U S A 1989, 86(5): I669-1673.

32. Dolan-Livengood JM, Miller YK, Martin LE, Urwin R, Stephens DS: Genetic basis for nongroupable Neisseria meningitidis. Infect Dis 2003, 187(10):1616-1628.

33. Hammerschmidt S, Birkholz C, Zahringer U, Robertson BD, van Putten J, Ebeling $O$, Frosch M: Contribution of genes from the capsule gene complex (cps) to lipooligosaccharide biosynthesis and serum resistance in Neisseria meningitidis. Mol Microbiol I994, I I(5):885-896.

34. Hashimoto Y, Li N, Yokoyama H, Ezaki T: Complete nucleotide sequence and molecular characterization of $\mathrm{ViaB}$ region encoding Vi antigen in Salmonella typhi. J Bacteriol 1993, I 75( I 4):4456-4465

35. Kroll JS, Zamze S, Loynds B, Moxon ER: Common organization of chromosomal loci for production of different capsular polysaccharides in Haemophilus influenzae. J Bacteriol 1989, I 7 I(6):3343-3347.

36. Swartley JS, Ahn JH, Liu LJ, Kahler CM, Stephens DS: Expression of sialic acid and polysialic acid in serogroup B Neisseria meningitidis: divergent transcription of biosynthesis and transport operons through a common promoter region. J Bacteriol 1996, I78( I 4):4052-4059.

37. Kondo S, Hisatsune K: Sugar composition of the polysaccharide portion of lipopolysaccharides isolated from non-OI Vibrio cholerae 02 to O4I, O44, and O68. Microbiol Immunol 1989, 33(8):64|-648.

38. Reeves PP, Wang L: Genomic organization of LPS-specific loci. Curr Top Microbiol Immunol 2002, 264(I): 109-135.

39. Bik EM, Bunschoten AE, Gouw RD, Mooi FR: Genesis of the novel epidemic Vibrio cholerae O 139 strain: evidence for horizontal transfer of genes involved in polysaccharide synthesis. Embo J 1995, I4(2):209-216.

40. Stroeher UH, Parasivam G, Dredge BK, Manning PA: Novel Vibrio cholerae 0139 genes involved in lipopolysaccharide biosynthesis. J Bacteriol 1997, I79(8):2740-2747.

41. Arita M, Takeda T, Honda T, Miwatani T: Purification and characterization of Vibrio cholerae non-OI heat-stable enterotoxin. Infect Immun I 986, 52(I):45-49.

42. de Lorenzo V, Herrero M, Jakubzik U, Timmis KN: Mini-Tn5 transposon derivatives for insertion mutagenesis, promoter probing, and chromosomal insertion of cloned DNA in gramnegative eubacteria. J Bacteriol 1990, I 72(I I):6568-6572.
43. Herrero M, de Lorenzo V, Timmis KN: Transposon vectors containing non-antibiotic resistance selection markers for cloning and stable chromosomal insertion of foreign genes in gram-negative bacteria. J Bacteriol 1990, I72(I I):6557-6567.

44. Ciucanu I Kerek, F: A simple and rapid method for the permethylation of carbohydrates. Carbohydrate Research 1984, | 3 |:209-2 |7.

45. Martin VJ, Mohn WW: An alternative inverse PCR (IPCR) method to amplify DNA sequences flanking Tn5 transposon insertions. J Microbiol Methods 1999, 35(2): 163-166.

46. Ewing B, Green P: Base-calling of automated sequencer traces using phred. II. Error probabilities. Genome Res 1998, 8(3): $186-194$

47. Ewing B, Hillier L, WendI MC, Green P: Base-calling of automated sequencer traces using phred. I. Accuracy assessment. Genome Res 1998, 8(3): 175-185.

48. Gordon D: Viewing and Editing Assembled Sequences Using Consed. In Current Procols in Bioinformatics Edited by: Baxevanis AD, Davison DB. New York, John Wilery \& Co.; 2004:I I.2.I-I I.2.43.

49. Altschul SF, Gish W, Miller W, Myers EW, Lipman DJ: Basic local alignment search tool. J Mol Biol 1990, 21 5(3):403-4I0.

50. Rutherford K, Parkhill J, Crook J, Horsnell T, Rice P, Rajandream MA, Barrell B: Artemis: sequence visualization and annotation. Bioinformatics 2000, 16(10):944-945.
Publish with Biomed Central and every scientist can read your work free of charge

"BioMed Central will be the most significant development for disseminating the results of biomedical research in our lifetime. "

Sir Paul Nurse, Cancer Research UK

Your research papers will be:

- available free of charge to the entire biomedical community

- peer reviewed and published immediately upon acceptance

- cited in PubMed and archived on PubMed Central

- yours - you keep the copyright
BioMedcentral 